\title{
Intramedullary sarcoidosis of the cervical spinal cord
}

\author{
ALAIN VIGHETTO, ${ }^{*}$ GEORGES FISCHER, $\dagger$ PHILIPPE COLLET,${ }^{*}$ \\ BERNADETTE BADY, $\ddagger$ MARC TRILLET*
}

From the Service de Neurologie du Professeur B Schott, * Hôpital Neurologique, Service de Neurochirurgie A, Faculté de Medecine Alexis Carrel, $\dagger$ Laboratoire d'Electromyographie, $\ddagger$ Hôpital Neurologique, Lyon, France

SUMMARY A 26-year-old male with a history of pulmonary sarcoidosis showed clinical, myelographic and intra-operative evidence of a C5-C6 spinal cord tumour, which was diagnosed by biopsy as a pure intramedullary granuloma. Among the 29 published cases of histologically proven cord sarcoidosis, only five presented with pure parenchymatous infiltration without meningeal involvement. Corticosteroids are the most useful therapy, and surgery is indicated only for minimal biopsy when the parenchyma is invaded.

Spinal cord involvement is a very rare but well documented manifestation of sarcoidosis. Including the first pathological description of the condition by Longcope in $1941,{ }^{1}$ only 29 cases of histologically proven spinal cord sarcoidosis diagnosed antemortem or postmortem have been published (reviews in refs 2, and 3-14). Anatomically, the lesions have been variously distributed within the spinal cord but almost invariably involve the meninges. We report a case of pure intramedullary granuloma without meningeal involvement, in which the clinical, radiological and intraoperative findings were suggestive of a cervical cord tumour.

\section{Case report}

A 27-year-old Algerian male was referred in October 1982 with a 2 months history of increasing bilateral arm weakness, difficulty in walking, and bladder urgency. He also complained of upper dorsal backache radiating to the anterior chest. His past medical history was remarkable only for pulmonary sarcoidosis. This condition had been diagnosed by bronchial biopsy five years previously, and treated with corticosteroid, levamisole and azathioprine until July 1981 .

\footnotetext{
Address for reprint requests: Dr Alain Vighetto, Service de Neurologie du Professeur M Devic, Hôpital Neurologique, BP Lyon Montchat-69394 Lyon Cedex 3, France.
}

Received 24 November 1983 and in revised form 12 August 1984. Accepted 22 August 1984
On examination, he was able to walk for only a few meters without aid. He had a spastic tetraparesis, which was more prominent on his right side. Severe amyotrophy was present in both hands, right greater than left, and was associated with continuous fasciculations which caused minimal finger displacements. All tendon reflexes were brisk, save for triceps reflexes which were inverted; bilateral extensor plantar responses were elicited. Pain and thermal sensation was moderately decreased below T4, and a hypoaesthetic band in the right $\mathrm{C} 8-\mathrm{T} 1$ territories was noted. Electromyography showed denervation bilaterally in the $\mathrm{C7}, \mathrm{C8}$, and $\mathrm{T} 1$ territories. Motor and sensory conduction velocities were normal in both arms. Somatosensory evoked potentials showed reduced amplitude and normal latency of the cervical $\overline{\mathrm{N} 11}$ and $\overline{\mathrm{N} 13}$ components following stimulation of the right median nerve. Visual evoked potentials were normal. Erythrocyte sedimentation rate, plasma calcium level, protein immuno-electrophoresis, plasma and urinary osmolalities were all normal. CSF was clear, with elevation of both protein content ( 1.66 g/l) and globulin fraction (17\%). Cell count ( 2 WBC. $\mathrm{mm}^{3}$ ) and glucose level $(2.8 \mathrm{mmol} / \mathrm{l})$ were normal. Bacterial and fungal cultures were negative. Angiotensin converting enzyme was $90 \mathrm{nmol} / \mathrm{mn} / \mathrm{ml}$ in serum (normal value $=35$ $\pm 10 \mathrm{nmol} / \mathrm{mn} / \mathrm{ml}$ ) and was not detected in CSF. Radiographs of the cervical spine were normal. Myelography demonstrated an enlargement of the cervical spinal cord between $\mathrm{C} 5$ and T1 levels, suggestive of an intramedullary lesion (fig a). Both cervical spinal angiography and total body gallium scintigraphy were normal. Head computed tomography showed only moderate ventricular enlargement.

A C3-T1 laminectomy was carried out. The dura was tense, and the underlying spinal cord was enlarged. Using an operation microscope, the posterior midline sulcus of 

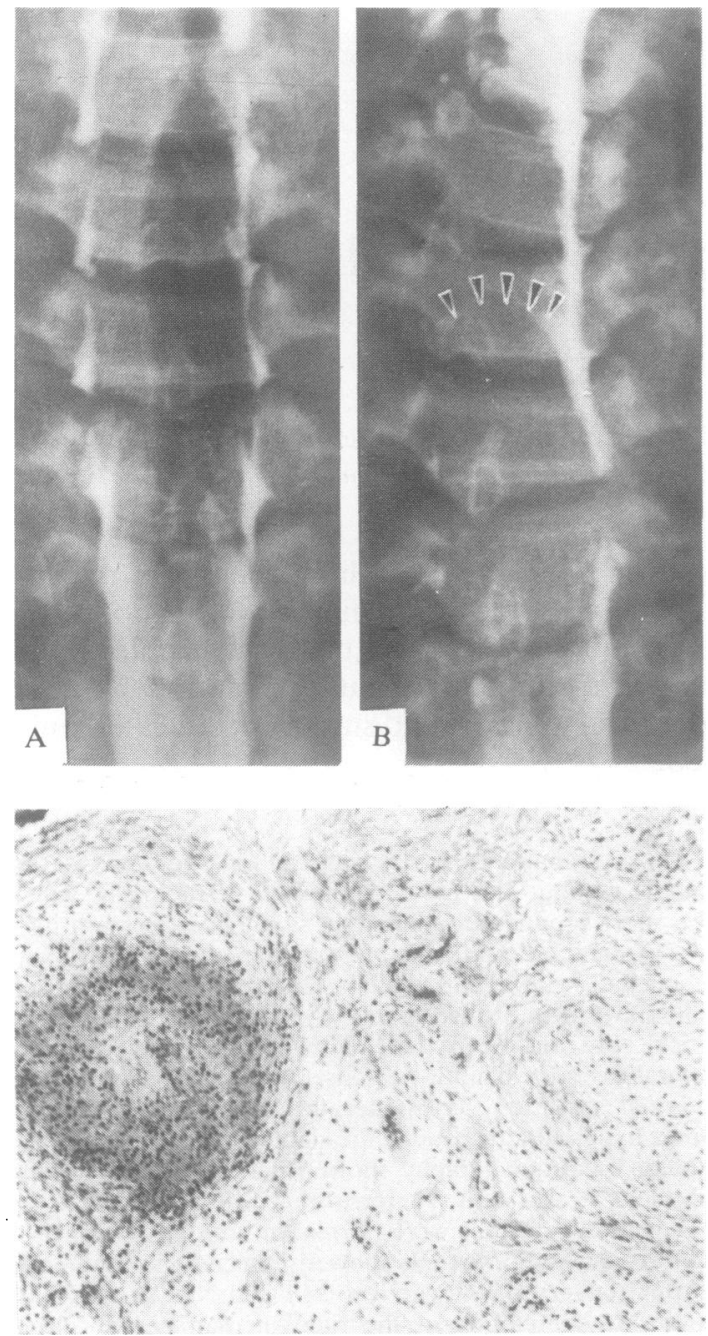

Fig (a) Myelogram. A antero-posterior projection: global widening of the cervical spinal cord. B left lateral projection: caudal pole of the lesion is visible at C7-T1 level and oral pole is outlined by contrast medium at C5 level (black arrows). (b) Histological findings: non caseating granuloma, with lymphocytes and epitheloid cells, surrounded by fibrosis (haematoxylin and eosine $\times 40$ ).

the cord was located and was then progressively widened. A tumour-like infiltrative lesion extending over $22 \mathrm{~mm}$ from $\mathrm{C} 5$ to $\mathrm{C} 6$ was found $2 \mathrm{~mm}$ beneath the surface. This lesion had no discernible plane of cleavage from the surrounding parenchyma, and was calcified and very hard to cut. A tissue biopsy was taken with much difficulty. Histology showed non-caseating nodular formations containing lymphocytes and epithelioid cells, surrounded by interstitial fibrosis with scattered calcifications (fig b). Although no giant cell was seen, these appearances were those of intramedullary spinal sarcoidosis. Histology of the pia was normal. No further extirpation of the lesion was attempted. After a transient-postoperative worsening of the tetraparesis, the patient gradually improved over the ensuing 6 months on methylprednisolone and physical therapy. He was then ambulatory with axillary crutches for about $80 \mathrm{~m}$ and had normal bladder control. However, recovery ceased and his condition deteriorated again a few months later with a resulting almost complete tetraplegia.

\section{Discussion}

Pathological changes are protean in neurosarcoidosis, and spinal cord involvement may variously be related to extramedullary mass, ${ }^{6} 1112$ pure leptomeningeal (case 8 in ref 15), mixed leptomeningeal and parenchymatous, ${ }^{78}$ or pure parenchymatous infiltration. This last condition has been reported in only five of the 29 histologically confirmed cases, with a tumour-like granuloma located at the cervical (case 2 in ref 2 ), ${ }^{1416}$ thoracic, ${ }^{17}$ or lumbar level..$^{5}$ Indeed, integrity of the leptomeninges was questionable in each case, as macroscopic description was sketchy and histology not mentioned. In our case the lesion was histologically a pure intramedullary spinal cord granulomos with verified sparing of the adjacent meninges. The clinical, radiological, and intra-operative finding were those of a cervical spinal cord infiltrative tumour, and the diagnosis, although suspected from the history of pulmonary sarcoidosis, could only b8 established through histological examination of the tissue biopsy specimen.

Spinal cord invasion is a serious complication of e sarcoidosis. Its treatment is based primarily upon corticosteroids. Some patients with a spinal cord syndrome complicating systemic sarcoidosis have been conservatively treated with high doses of steroids, and have demonstrated significant clinical improvement, ${ }^{18} 19$ including a return of the myelographic appearances to normal. ${ }^{20}$ Although individual patients do vary in their response, this is at present the only way to improve or at least to stabilise the neurological condition. The role of surgery remains more controversial. In terms of functional prognosis, total or subtotal extirpation of the lesion appears to be beneficial in the cases with an extramedullary mass, ${ }^{112}$ but disastrous in the cases with an intramedullary lesion. ${ }^{21617}$ On the other hand, very limited tissue biopsy by an experienced neurosurgeon seems to be a relatively innocuous procedure in the latter group. ${ }^{2122}$ Biopsy is obvi- $\rightarrow$ ously of critical importance when spinal sarcoidosis occurs as the initial manifestation of the dis- $N$ ease, ${ }^{21016}$ but is also to be considered in patients with longstanding history of sarcoidosis, particularly 
when previous immunosuppressive treatment and unusual clinical presentation raise the possibility of spinal cord neoplasm.

The authors are grateful to Drs M Perrin Fayolle, $\mathbf{M}$ Tommasi, J Duquesnel, F Mauguiere, and A Mandell for their contributions to the study.

\section{References}

' Longcope WT. Sarcoidosis or Besnier Boeck Schaumann disease. JAMA 1941;117:1321-7.

${ }^{2}$ Day AL, Sypert GW. Spinal cord sarcoidosis. Ann Neurol 1977;1:79-85.

${ }^{3}$ Vogtch H. 1949, cited in (5).

${ }^{4}$ De Morsier G, Maurice P, Martin F. Besnier Boeck diffus des muscles et lésions du systéme nerveux central. Acta Neurol Belg 1954;54:34-51.

${ }^{5}$ Garcin R. Sarcoïdose de la moëlle lombo-sacrée. Livre Jubilaire du Docteur Ludo Van Bogaert, Bruxelles Acta Med. Belg, Ed. 1962:301-9.

- Girard PL, Cournil C, Quenum C, Sarrat H, Dumas M. Compression médullaire par épidurite d'allure sarcoïdosique. Bull Soc Afr Noire Lang Franc 1975; 20:31-41.

' Buge A, Escourolle R, Poisson M, Rancurel G, Gray F. Sarcoïdose médullaire. Ann Méd Interne (Paris) 1975; 126: 1-16.

${ }^{8}$ Nathan MPR, Chase PH, Elguezabel A, Wenstein M. Spinal cord sarcoidosis. NY State J Med 1976; 76: 748-52.

"Snyder R, Toufighi J, Gonatas NK. Sarcoidosis of the spinal cord. J Neurosurg 1976;44:740-3.
${ }^{10}$ Bernstein J, Rival J. Sarcoidosis of the spinal cord as the presenting manifestation of the disease. South Med J 1978; 71:1571-3.

" Baruah JK, Glasauer FE, Sil R, Smith BH. Sarcoidosis of the cervical spinal canal: case report. Neurosurgery 1978;3:216-8.

${ }^{12}$ Kanoff RB, Ruberg RL. Sarcoidosis presenting as a dorsal spinal cord tumour: report of case. JAOA 1980;79:765-7.

${ }^{13}$ Cahill DW, Salcman M. Neurosarcoidosis: a review of the rarer manifestations. Surg Neurol 1981;15:20411.

${ }^{14}$ Rubinstein I, Hiss J, Baum GL. Intramedullary spinal cord sarcoidosis. Surg Neurol 1984;21:272-4.

is Matthews WB. Sarcoidosis of the nervous system. $J$ Neurol Neurosurg Psychiatry 1965;28:23-9.

${ }^{16}$ Banerjee T, Hunt WE. Spinal cord sarcoidosis. J Neurosurg 1972;36:490-3.

17 Semins H, Nugent GR, Chou SM. Intramedullary spinal cord sarcoidosis. J Neurosurg 1972;37:233-6.

${ }^{18}$ Magnet JL, Strauss J, Guard O. Localisation intramédullaire d'une sarcoïdose (?). Nouv Presse Méd 1980;9:1518.

19 Viader F, Dairou R, Elghozi D, Bolgert F, Masson M. Myélopathie cervicale révélatrice d'une sarcoïdose. Nouv Presse Méd 1982;11:1805.

${ }^{20}$ Kirks DR, Newton TH. Sarcoidosis: a rare cause of spinal cord widening. Radiology 1972;102:643.

${ }^{21}$ Jefferson M. Sarcoidosis of the nervous system. Brain 1957;80: 540-56.

${ }^{22}$ Fazlullah S. Sarcoidosis with involvement of the nervous system. Dis Chest 1962;41:685-8. 